\title{
Paternal uniparental disomy of chromosome $\mathrm{X}$
}

INSERM

\section{Source}

INSERM. (1999). Orphanet: an online rare disease and orphan drug data base. Paternal uniparental disomy of chromosome X. ORPHA:261524

\begin{abstract}
A uniparental disomy of paternal origin that does not seem to have an adverse impact on the phenotype of an individual. There is a possibility of homozygosity for a recessive disease mutation for which the father is a carrier and specific phenotype depends on the inherited disorder.
\end{abstract}

